\title{
THE ROLE OF FINANCIAL STRUCTURE, BUSINESS DRIVE, BUSINESS ENVIRONMENT ON DECISION TO USE AN EXTERNAL AUDITOR ON SMES: EVIDENCE FROM ASEAN COUNTRIES
}

\author{
Jonathan ${ }^{1 *}$, Moch. Doddy Ariefianto ${ }^{2}$, and Rindang Widuri ${ }^{3}$ \\ 1,2,3 Accounting Department, BINUS Graduate Program Master of Accounting, \\ Bina Nusantara University, Jakarta, Indonesia 11480 \\ 1.jonathan043@binus.ac.id, ${ }^{2}$ moch.areifianto@binus.edu, ${ }^{3}$ rindangw@binus.edu
}

Received: $17^{\text {th }}$ February $2021 /$ Revised: $27^{\text {th }}$ November $2021 /$

Accepted: $08^{\text {th }}$ December 2021

How to Cite: Jonathan, Ariefianto, M. D., \& Widuri, R. (2021). The role of financial structure, business drive, business environment on decision to use an external auditor on SMEs: Evidence from

ASEAN countries. Journal of ASEAN Studies, 9(2), 159-180.

https:/doi.org/ 10.21512/jas.v9i2.7070

\begin{abstract}
The research examined the role of financial structure, business drive, and business environment that resulted in external audit service adoption in small and mediumsized enterprises (SMES) within ASEAN countries. Source of data were from the 2015 and 2016 World Bank Enterprise Survey. The research discovers that external audit service adoption is significantly influenced by financial structure, business motivation, and business environment. Additionally, we take into account a number of control variables, including sales, ownership structure, industry sector, and country of origin. The findings indicate a significant positive correlation between sales, ownership structure (partnership vs. sole proprietorship), and external audit adoption for SMEs. From a country-of-origin perspective, it is concluded that audit adoption is significantly higher in Malaysia and the Philippines than in Vietnam. However, audit adoption in Indonesia is significantly lower than in Vietnam, both in terms of awareness and implementation. Other points of interest can be seen in the interaction regression between countries, which indicates the degree of complexity associated with audit adoption when country of origin is taken into account. One significant policy implication is that SMEs can leverage external auditor services to support their growth and, in turn, the economy of the corresponding country.
\end{abstract}

Keywords: external auditor, SMEs, financial structure, business drive, business environment 


\section{INTRODUCTION}

Prior to any decision making for the company, several considerations are the defining factors. This involves company decision's when contracting external auditor service. In the case of a public company, an external auditor is a mandatory requirement in order to fulfill company responsibility to their shareholders. However, this is not the case with small and medium-sized enterprises (SMEs). A lot of SMEs decided to not use external auditor service. One of the main reasons being cost consideration, small to non-existent volume of stakeholders. There are no requirements for SMEs in Indonesia to use an external auditor. In Malaysia, Kamarudin \& Abidin (2012) concluded that SMEs in Malaysia believe they are required to have audited financial statements due to regulatory requirements, rather than the audit's value and associated benefits. However, Anuar, Devi, and Meng (2012) shares different opinion. They explain that SMEs in Malaysia mainly opt-in auditing to compensate their lack of tangible (professional/qualified accountants) and intangible (accounting and business expertise) resources.

Elkhatib and Kamel (2013) conclude that the primary function of auditing is to review material changes in accounting policies and practices. However, SMEs are unlikely to prioritize the inclusion of external audit services in their business processes if they are not required to. More research on the cost consideration, a study has been conducted in a survey back in 2013 by the Financial Executive Research Foundation (FERF) on 255 U.S. entities (listed companies, closed companies, and nonprofits) reporting external audit fees with a median of $0,07 \%$ of annual revenue. Auditing can be prohibitively expensive for very small businesses, the median is $1,05 \%$, a maximum of $3,09 \%$ of annual income. These external auditors services vary greatly, some of the factoring points include firm's experience, audit quality, and also services offered. These considerations, in turn helped establish the industry title of "The Big 4 Auditor" which held precedence in terms of audit quality, on global scale. As a matter of fact, accredited external auditors are a common occurrence for businesses, including small and medium-sized enterprises (SMEs).

Additionally, according to Peel and Bridge (1999), SMEs have as one of their strategic objectives "reducing business costs." This practice encourages SMEs to prioritize allocating existing funds to meet specific business needs. Additionally, there appears to be an underestimation of auditing risk; additionally, technological advancements have the potential to reduce auditing costs. As a result, small entities with comparable audit capabilities may benefit from more comprehensive auditing.

Businesses without external auditor aid and knowledge might miss on several key growth opportunity. Subsequently, if the same scenario is applied to a country where SMEs constitute the majority of the economy, the result will be a negative Gross Domestic Product (GDP). As a result, the discussion of why some SMEs choose to hire an external auditor is considered an interesting subject. Due to the critical role that SMEs play in the economies of the majority of countries worldwide, it is widely accepted that SMEs are significant contributors to global employment and GDP (Coetzee \& Buys, 2017). However, the debate 
over the factors affecting a company's willingness to use external audit services voluntarily continues.

The main interest upon this discussion is to analyze the role of company's financial structure, company's business driver strategy and company's business environment that resulted in usage of external audit services for SMEs in ASEAN. The research on such cases is fairly limited, especially for ASEAN region. Thus, research suggests that some SMES have favorable opinions on the audit function and its value for the company.

The research will be purposefully cover several area, so it could be referred to for: 1) Scientific purpose since it contributes to the existing literature on SMEs and audits, particularly issues in the audit market. Specifically, the contribution will take form as a research conducted in ASEAN, with its multidimensional variables (financial structure, business drive and business environment). There are presumably no research that specifically discuss the relationship between business drive and business environment towards the decision to use external auditor; 2) Practical purpose for business since it provides practical insights on the use of an external audit that will contribute to business success. This research will support ASEAN-based SMEs when they decide to adopt audit in their business process; 3) Regulator as it provides insights to help audit regulators improve audit-related regulations effectively.

The research focuses on SMEs in selected countries within Southeast Asia countries, such as Indonesia, Malaysia, Philippines, Thailand, and Vietnam from World Bank Enterprise Survey in 2015-2016. It is considered necessary since different countries also imbue their businesses with distinctive components. Additionally, the countries selected from Southeast Asia are Tiger Cub Economies, which refers to Southeast Asia's developing economies. The term cub indicates that the countries are in their infant stages, indubitably, the SMEs in these countries can also contribute to the country's economic morphogenesis. With such a broad scope, the research aims to ascertain the factors that influence SME decision-making regarding the use of an external audit service, particularly in the ASEAN region. Therefore, the research question is developed: What role does a company's financial structure, business motivations, and business environment play in small and medium-sized businesses in ASEAN deciding to adopt external audits?

\section{LITERATURE REVIEW}

Apart from the absence of obligation for financial report audit on SME, cost consideration and such, an audit is also proven to be beneficial for the business process of a company. The role of external auditors for companies is often inseparable from the stakeholders' need to obtain assurance for the account reported within the financial statements. Financial report is proven to have an indirect effect on business decisions made by business owners, as stated in the Statement of Financial Accounting Standards PSAK No. 1. The presentation clarifies financial statements to provide key information regarding the financial positions, performance, and changes in the financial positions of companies. This information is commonly used by a large number of users in economic decision-making, 
especially for users who collect earnings from the business. The assurance required for financial reports is commonly considered within several factors in mind. The factors are differences between the parties carrying out accounting activities with business actors, the insufficient ability of business actors to analyze financial reports, and the need for external parties to guarantee the financial statements credibility themselves.

Other audit function for business, especially SMEs is further explored by Hien, Abbott, and Huyen (2016) concluding that independent auditor service have a positive influence on credit access in Vietnamese SMES. Furthermore, some SMEs are willing to accommodate higher bills to contract globally qualified auditor firms. A similar case has been studied further by Louis (2005) who tries to look for independent variables as to why a small company seeks for the Big 4 services. He concludes that these firms offer much superior services. Hay (2020) also mentions this about the value of auditing with regard on audits of smaller, unlisted companies and audits of voluntary organizations, such clubs or charities, are also an area that is not extensively researched. Other implication such as agency conflict within corporate and non-optimal fund source might be accessed by the company. Carey, Simnett, and Tanewski (2000) and Vanstraelen and Schelleman (2017) go over independent factors that triggers voluntary internal and external audit within a family business. The results of the study shows that agency conflict, size, complexity, level of debt, and financial condition of the company are the key factors that family business considers prior to adopting voluntary audit.

The research uses three major variables as independent variables to determine whether to hire an external auditor. This might begin with considering the structure. When it comes to running a business, growth is unavoidable. However, the company's development and expansion will require additional funding. There are many financing options for companies to fulfill their business expansion plans, one of which is through bank loans or other financing options.

According to Hermas and Tahavainen (2002), firms attempt to minimize the financing costs by opting first to the internal finance before turning to external. If external financing is required, the firm will issue next external debt and lastly external equity. However, SMEs often face difficulty accessing credit from banks or third parties. This claim is supported by Schiffer and Weder (2001) arguing that SMEs frequently experience roadblock when trying to access credit. In general, banks or other third parties assess the quality of the company through the information in the financial statements. Caneghem and Campenhout (2010) discover that both types of information are frequently used as leverage. Additionally, these findings support the view that firms cannot access external financing due to a lack of qualified information. Naturally, when discussing financial statement quality, it cannot be seperated from the report's content. Furthermore, on Greek manufacturing SMEs, Voulgaris, Asteriou, and Agiomigianakis (2000) argues that as return on total assets and net profit margin, it is believed to have the strongest effect on all types of debt but negatively correlated with external financing. It is believed that the quality and content of financial statements also need to be accurate. Thus, SMEs turn to institutions who have the capability to produce a qualified financial report. 
The use of an external auditor as an institution that can provide assurance to financial statements can certainly be one of the company's main considerations to obtain a good corporate financial structure. Palazuelos, Crespo, and Corte (2017) conduct a research involving 471 bank officers to drew conclusions based on the opinions from bank loan officers in Spain, where they discover a positive relationship between audited SMEs, the perception that the accounting information has a direct on loan officers' willingness to grant them credit. Therefore, even though there is no obligation for SMEs to audit their financial statements, the use of an external auditor can support SMEs to have better quality financial reports, so the company can have better quality financial structure. Therefore, the research classifies financial structure into three categories, namely: 1) owners loan or line of credit, 2) overdraft, and 3) working capital.

Hypothesis $1\left(\mathrm{H}_{1}\right)$ : There is a positive relationship between financial structure and SMEs decision to use external audit.

Secondly, business drive or business model design is often associated with innovation. Most of the enterprises, especially SMEs have little knowledge and awareness about the critical importance of business model innovation (Marolt et al., 2016). Marolt et al. (2016) conclude that the external opportunity is the main driver that solidify SMEs' decision to innovate their business model. External opportunity is described as changes in key technologies, which might illustrate that companies often innovate to support business drive strategy or simply because they follow the trends. According to Kesting and Günzel-Jensen (2015), business model sophistication affects all businesses, but particularly new ventures and small and medium-sized enterprises. On the basis of the preceding discussion, it is argued that startups should be constantly on the lookout for sophisticated opportunities when developing a business model for their market offering. There are numerous ways for businesses to grow while focusing on technology development that supports their business model innovation. However, the use of an external auditor can be considered as one of the factors affecting the company's decision when designing the business drive strategy.

Irmawan, Hudaib, and Haniffa (2013), supported by Hay (2020), define an external auditor or independent auditor as an assurance for financial information reports produced by companies and bottom line helps increase the confidence in the capital market and improve the company's market value. In addition, Wallace (2004) argues that the use of auditor services also ensures investors that management has high credibility in presenting financial information. This credibility comes from the aspect of technical precision. The business drive strategy carried out by the company while using external auditors can certainly be seen in terms of the credibility of the auditors and the quality of the audited financial statements, so that external parties can assess the company as a credible entity. The audit quality often ties back to the predicate Big 4 auditors which might also add value to the company when a company presents audited financial reports.

Therefore, the research classifies business drives in SMEs into four categories, namely: 1) top management experiences, 2) foreign licensed software, 3) own website, and 4) using e-mail. The research considers SMEs with the aforementioned facilities are businesses 
driven by a business strategy. Therefore, the research identifies whether companies that have an overview of business drives also include external audit as a support of the business drive strategy. In the case of SMEs, the use of these audits is very different from that of their larger counterparts. It is assumed that no research has been done on the relationship between business drive and external auditing.

Hypothesis $2\left(\mathrm{H}_{2}\right)$ : There is a positive relationship between business drive and SMEs' decision to use external audit.

The third is business environment. While running a business, the decision to choose the business environment is considered important since certain business environment can support business activities. Schiffer and Weder (2001) conclude that smaller firms face significantly more problems than larger firms in terms of financing, taxes and regulations, inflation, corruption and street crime. There are eight business environments that affect company size, including: 1) taxes and regulations, 2) instability policy, 3) inflation, 4) exchange rates, 5) the judiciary, 6) corruption, 7) street crime, 8) organized and anticompetitive practice (Schiffer \& Weder, 2001). Bad business environment is thought to have a detrimental effect on the business. Additionally, the World Bank states that business environment factors can have an effect on the development of SMEs (Schiffer \& Weder, 2001). A study on bad business environment impact on business development could be seen in a research by Olawale and Smit (2010) which conclude that crime and bad macroeconomic environments have positive and significant correlations with non-accessible debt financing to new SMEs.

The research analyzes the relationship between an inadequate business environment and a company's decision to use an external auditor based on the foregoing discussion. It is assumed that owners have the consideration to hire external auditors voluntarily, in the same manner a bad business environment that requires owners to hire external audits to avoid bad perspectives from external parties (banks, other financial institutions) which cause difficulties for companies to access bank loans. Business owners also consider an external auditor to be even more important if the company's business activities are revolving around a bad business environment. The research classifies the business environment in SMEs into two categories, namely: 1) budget for security; 2) losses as a result of theft, robbery, and vandalism. There has not been a research that discusses the relationship between business environment and the use of external audit.

Hypothesis $3\left(\mathrm{H}_{3}\right)$ : There is a positive relationship between a better business environment and SMEs decision to use external audit.

\section{RESEARCH METHODS}

As an ordered logistic function, the research models the relationship between the dependent variable AUDIT: 


$$
Y_{i}^{*}=X \beta+V \gamma+u_{i} ; E\left(u_{i}\right)=0
$$

in which the cut-off the latent variable for category $\mathrm{j}$ of dependent variable $*$ is given by

$$
\begin{aligned}
& Y_{i}=1 ; 1<Y_{i}^{*}<\infty \\
& Y_{i}=0 ; \quad-\infty<Y_{i}^{*}<\infty
\end{aligned}
$$

where $\mathrm{Y}$ is ordinal scaled dependent variable (AUDIT). $\mathrm{X}$ is the vector of variable of interest regressors and $\mathrm{V}$ is the vector of control regressors. The latent variable subsequently converted to probability belongs to category $\mathrm{j}$ through a logistic function.

The research has 16 regression models to covering a substantial portion of rich information provided in the data set. From that point, various items in the questionnaire are combined into three key metrics: 1) A measure of company's financial structure (FINSTRU), 2) A measure of company's business drive strategy (BUSDRIVE), and 3) A measure of company's business environment (BUSENV). The research determines the value by analyzing the relationship between costs and benefits of the audit that hopefully will bring advantages to the company. In analyzing the factors affecting SMEs' decision to use external audits, the research reviews several variables that might affect a company's decision, whose codes are provided in Table 1.

a. Financial Structure

It is a multidimensional variable that measures the extent of financial reliance on an outer source. The calculation for this variable is the sum of (a). Line of Credit Facility, (b). Overdraft Facility and (c). 1-Retained Earnings (K3a). We will treat qualitative answers $(\mathrm{Yes} / \mathrm{No})$ as an ordinal scale, in which $\mathrm{Yes}=1$ and $\mathrm{No}=0$. For numeric variables, we transform the variables using the $\mathrm{S}$ function.

b. Business Drive

It is a multidimensional variable to measure the extent of SMEs business driver factor. The calculation for this variable consists of the sum value from these variables (a). Top Management Experience (B7), (b). Usage of Foreign License Office Software (E6), (c). Own Website (C22b), and (d). Use eMail (C22a). We treat this variable through qualitative means $(\mathrm{Yes} / \mathrm{No})$ or as an ordinal scale, in which $\mathrm{Yes}=1$ and $\mathrm{No}=0$. For numeric variables, we will transform using the $\mathrm{S}$ function.

c. Business Environment

It is a multidimensional variable to measure the SMEs Business Environment. It is calculated by summarizing the answers to questions of (a). Pay for Security (I1), (b) Experience Losses As A Result Of Theft, Robbery, Vandalism Or Arson (I3). We measure these questions through qualitative answers (Yes/No) or as an ordinal scale, in which $Y e s=1$ and $\mathrm{No}=0$. For numeric variables, we transform using the $\mathrm{S}$ function.

Several control variable are calculated using: 1) country dummy, which will be used to set some boundaries within research that is being conducted in the country of interest, done due to the difference between each country policy that endorse audited financial reports; 2) company sales value that will be convert into USD currency, by using sales as a control 
variable, the research aims to set the sales performance to determine company size; 3) business sector, moving forward this variable will cascade each sector into specific clusters, this is necessary to check if specific business sectors are interested to adopt audit into their business process.

Lastly, the ownership structure in a company definitely influences the decisionmaking. In this case, the decision to use an external auditor is expected to be voluntary or due to external pressure that requires the company to hire an external audit. Research by Anuar et al. (2012) in Malaysia finds a positive association between different modes of ownership structure and SMEs opting for voluntary audits.

However, in Canada, Senkow et al. (2001) do not find a significant relationship between managerial ownership and voluntary audits. Therefore, the research considers the level of complexity of the ownership structure that influences the decision to hire external auditors voluntarily. This is also supported by Collis (2009) and Desender et al. (2009), who find that the ownership structure has a significant influence on the relationship between the demand for external audit and executive board characteristics. However, Collis (2009) adds that demand for voluntary audit by small companies is a result of demand from shareholders and the bank/lenders (agency factors), but the demand from shareholders is predicted to be the more powerful of the two.

This research also determines whether the higher level of complexity in ownership of a company is considered to be high. There are various types of ownership that have different levels of complexity, and these types of ownership is considered to vary greatly. The reserach considers more complex ownership structure leads to higher company's desire to use an external auditor service voluntarily.

The research tests the feasibility of the regression results using the Hosmer-Lemeshow Test \& Pseudo R2 Test. The Hosmer-Lemeshow Test is a goodness of fit test for logistic regression. A goodness of fit test can describe how well the data fits the model. Appropriate is defined as the absence of a significant difference between the model and its observed value. Additionally, we used the Pseudo R Square to determine the independent variable's ability to explain the dependent variable. The results demonstrate the independent variable's ability to adequately explain the dependent variable in percentage units. The remainder denotes an extraneous factor that exists outside the model and contributes to the explanation of the dependent variable.

The basic model is extended to include company's domicile (C_ID, C_MY, C_PH, C_VI, and C_TH), classification based on company's ownership structure, and also classification based on company business sector (BSECS_MA, BSECS_OS, BSECS_RS). In addition to the assumption test on the final model, the research conducts robustness checks throughout the variables of interest (FINSTRU, BUSDRIVE, and BUSENV). This is to determine whether each of these variables has an effect on the estimated results. Explaining chronological research includes how to prepare materials research, design of the study and research procedures. Minimum research method consists of research type, type and source of data, data collection techniques, and data analysis techniques. 
Table 1. Description of Variables

\begin{tabular}{|c|c|c|c|c|c|}
\hline \multirow{2}{*}{ Variables } & \multirow{2}{*}{ No } & \multirow{2}{*}{ Proxy } & \multirow{2}{*}{ Description } & \multicolumn{2}{|c|}{ WB ES Questionnaire Source } \\
\hline & & & & Code & Question \\
\hline $\begin{array}{l}\text { Dependent } \\
\text { Variable }\end{array}$ & 1 & AUDIT & $\begin{array}{l}\text { The Use of External } \\
\text { Auditor }\end{array}$ & $\mathrm{K} 21$ & $\begin{array}{l}\text { In fiscal year [insert last complete } \\
\text { fiscal year], did this establishment } \\
\text { have its annual financial statements } \\
\text { checked and certified by an } \\
\text { external auditor? }\end{array}$ \\
\hline \multirow[t]{9}{*}{$\begin{array}{l}\text { Variable of } \\
\text { Interest }\end{array}$} & 1 & FINSTRU & Financial Structure & K8 & $\begin{array}{l}\text { At this time, does this } \\
\text { establishment have a line of credit } \\
\text { or a loan from a financial } \\
\text { institution? }\end{array}$ \\
\hline & & & & K7 & $\begin{array}{l}\text { At this time, does this } \\
\text { establishment have an overdraft } \\
\text { facility? }\end{array}$ \\
\hline & & & & $\mathrm{K} 3 \mathrm{a}$ & $\begin{array}{l}\text { Internal funds or retained earnings; } \\
\text { Over fiscal year [insert last } \\
\text { complete fiscal year], please } \\
\text { estimate the proportion of this } \\
\text { establishment's working capital, } \\
\text { that is the funds available for day- } \\
\text { to-day operations, that was } \\
\text { financed from each of the } \\
\text { following sources? }\end{array}$ \\
\hline & 2 & BUSDRIVE & Business Drive & B7 & $\begin{array}{l}\text { How many years of experience } \\
\text { working in this sector does the Top } \\
\text { Manager have? }\end{array}$ \\
\hline & & & & E6 & $\begin{array}{l}\text { Does this establishment at present } \\
\text { use technology licensed from a } \\
\text { foreign-owned company, excluding } \\
\text { office software? }\end{array}$ \\
\hline & & & & $\mathrm{C} 22 \mathrm{a}$ & $\begin{array}{l}\text { At the present time, does this } \\
\text { establishment use emails to } \\
\text { communicate with clients or } \\
\text { suppliers? }\end{array}$ \\
\hline & & & & $\mathrm{C} 22 \mathrm{~b}$ & $\begin{array}{l}\text { At the present time, does this } \\
\text { establishment have its own } \\
\text { website? }\end{array}$ \\
\hline & 3 & BUSENV & Business Environment & I1 & $\begin{array}{l}\text { In fiscal year [insert last complete } \\
\text { fiscal year], did this establishment } \\
\text { pay for security, for example } \\
\text { equipment, personnel, or } \\
\text { professional security services? }\end{array}$ \\
\hline & & & & $\mathrm{I} 3$ & $\begin{array}{l}\text { In fiscal year [insert last complete } \\
\text { fiscal year], did this establishment } \\
\text { experience losses as a result of } \\
\text { theft, robbery, vandalism or arson } \\
\text { on this establishment's premises? }\end{array}$ \\
\hline \multirow[t]{9}{*}{$\begin{array}{l}\text { Control } \\
\text { Variable }\end{array}$} & 1 & SALES & Sales Amount in USD & D2 & $\begin{array}{l}\text { In fiscal year [insert last complete } \\
\text { fiscal year], what were this } \\
\text { establishment's total annual sales } \\
\text { for ALL products and services? }\end{array}$ \\
\hline & 2 & C_ID & Country - Indonesia & A1 & Country \\
\hline & & C_MY & Country - Malaysia & & \\
\hline & & C_PH & Country - Phillipines & & \\
\hline & & $\mathrm{C}_{-}^{-} \mathrm{TH}$ & Country - Thailand & & \\
\hline & & $\mathrm{C}_{-}^{-} \mathrm{VI}$ & Country - Vietnam & & \\
\hline & 3 & BSECS_MA & $\begin{array}{l}\text { Business Sector - } \\
\text { Manufacture }\end{array}$ & A0 & Business Sector \\
\hline & & BSECS_RS & $\begin{array}{l}\text { Business Sector - Retail } \\
\text { Service }\end{array}$ & & \\
\hline & & BSECS_OS & $\begin{array}{l}\text { Business Sector - Other } \\
\text { Service }\end{array}$ & & \\
\hline
\end{tabular}




\begin{tabular}{lll}
\hline 4 & OWNST_SP & $\begin{array}{l}\text { Ownership Structure - } \\
\text { Sole Proprietorship }\end{array}$ \\
& BWNST_PS & Ownership Structure - \\
& Partnership. The \\
& combination of partner \\
& business category \\
& (private or public), due \\
& to limited respondent in \\
& some observed country \\
\hline
\end{tabular}

Source : World Bank Enterprise Survey

https://www.enterprisesurveys.org/en/enterprisesurveys

\section{RESULTS AND DISCUSSIONS}

\section{Descriptive Statistics}

Table 2 presents descriptive statistics for the variables utilized within this research. AUDIT will hold a minimum value of 0 and maximum on 1 . This categorization is required because this research conducted on an ordinal scale with qualitative answers ( $\mathrm{Yes}=1 / \mathrm{No}=1$ ). If AUDIT acquired a standard deviation value of 0,477 (above mean value), this implies AUDIT possesses high data variation. SALES have a minimum value of 2,556 and max value of 9,597. Within this variable, we convert sales value from native regional currency into USD, afterwards, the monetary value converted using a log algorithm.

Next, for FINSTRU and BUSDRIVE, the minimum - maximum value acquired are: 0,$078 ; 2,687 ; 0,176 ; 3,986$ both scored standard deviation value of 0 ., and 0,887 respectively (under mean value) which indicate that FINSTRU \& BUSDRIVE have data variation level that is lower than the mean value. FINSTRU \& BUSDRIVE is calculated with a simple sum of answers to questions within the respective proxy. Inside FINSTRU \& BUSDRIVE proxy also presents several numeric variables that will later be transformed using $\mathrm{S}$ function. Numeric variables in FINSTRU being mentioned illustrates retained earning percentages. On the other hand, BUSDRIVE symbolize top management experience measured in years of experience they currently have. Lastly, BUSENV with minimum value of 0 and maximum value of 2 . The value is operated using simple sum operation of the ordinal scale of the particular variable. BUSENV held Standard Deviation value of 0,608 (above mean) which indicates high data variance.

Table 2. Descriptive Statistics of Variables

\begin{tabular}{lccccc}
\hline Variable & \multicolumn{1}{c}{ Obs } & \multicolumn{1}{c}{ Mean } & Std. Dev. & Min & Max \\
\hline AUDIT & 3813 & 0,351 & 0,477 & 0 & 1 \\
SALES & 3813 & 5,334 & 0,833 & 2,556 & 9,597 \\
FINSTRU & 3813 & 1,017 & 0,624 & 0,078 & 2,687 \\
BUSDRIVE & 3813 & 1,568 & 0,887 & 0,176 & 3,986 \\
BUSENV & 3813 & 0,478 & 0,608 & 0 & 2 \\
\hline
\end{tabular}


It starts with 3,940 observations and then exclude null-valued responses. After filtering out the foregoing observations, 3,813 observations will be analyzed. The lower part is number of cases in each category of dependent and explanatory variables, as seen in Table 3 .

Table 3. Cases of Categorical Variables

\begin{tabular}{lcccccc}
\hline & Indonesia & Malaysia & Phillipines & Thailand & Vietnam & Total \\
\cline { 2 - 6 } AUDIT & 119 & 294 & 636 & 140 & 152 & \\
Non-Audit & 810 & 395 & 177 & 563 & 527 & \\
\cline { 2 - 5 } Responses & $\mathbf{9 2 9}$ & $\mathbf{6 8 9}$ & $\mathbf{8 1 3}$ & $\mathbf{7 0 3}$ & $\mathbf{6 7 9}$ & \multirow{3}{*}{} \\
& & & & & & \\
BSECS_MA & 722 & 372 & 602 & 469 & 426 & \\
BSEC_OS & 110 & 173 & 104 & 128 & 204 & \\
BSEC_RS & 97 & 144 & 107 & 106 & 49 & \\
\cline { 2 - 6 } & $\mathbf{9 2 9}$ & $\mathbf{6 8 9}$ & $\mathbf{8 1 3}$ & $\mathbf{7 0 3}$ & $\mathbf{6 7 9}$ & \multirow{3}{*}{3813} \\
OWNST_PS & 266 & 464 & 514 & 438 & 282 & \\
OWNST_SP & 663 & 225 & 299 & 265 & 397 & \\
\cline { 2 - 6 } & $\mathbf{9 2 9}$ & $\mathbf{6 8 9}$ & $\mathbf{8 1 3}$ & $\mathbf{7 0 3}$ & $\mathbf{6 7 9}$ & $\mathbf{3 8 1 3}$ \\
\hline
\end{tabular}

Table 4. Pearson's Correlation Table

\begin{tabular}{lcclcc}
\hline & AUDIT & SALES & FINSTRU & BUSDRIVE & BUSENV \\
\hline AUDIT & 1,000 & & & & \\
SALES & 0,195 & 1,000 & & & \\
FINSTRU & 0,066 & 0,239 & 1,000 & & \\
BUSDRIVE & 0,211 & 0,398 & 0,197 & 1,000 & \\
BUSENV & 0,253 & 0,249 & 0,105 & 0,311 & 1,000 \\
\hline
\end{tabular}

Table 4 summarizes a simple correlation (Pearson's Correlation) between the variables of interest used in the research. Afterward, we use Kendall's Tau to test the relationship between variables on an ordinal scale, according to Cleff (2019). Additionally, the research examines the relationship between control variables. Thus, it is concluded that there is no significant correlation between control variable and each independent variable, and that each independent variable exists independently of the others.

\section{Baseline Regression}

First, the research performs ordered logistic regression and supported by regression using a linear probability model and probit model. As Table 5 illustrates, for the $3^{\text {rd }}$ model, Pseudo R2 shows the value of 0,239 . This indicates that the independent variable could account for $23,9 \%$ of the dependent variable, but the model of significance is to be considered 
when practicing the logistic model. Furthermore, the correctly classified percentage scores on $77,76 \%$, which describes the proportion of the subject is considered to be well-classified. The research also finds strong empirical support for the variable of interest: 1) financial structure (FINSTRU), 2) business drive (BUSDRIVE), and 3) business environment (BUSNEV). To add to this formula, three different models are applied, the level of significance for each variable of interest showed equal value. BUSDRIVE \& BUSENV is statistically significant at the $1 \%$ level. However, FINSTRU is statistically significant at the $5 \%$ level.

For BUSDRIVE variable, the findings comes to support the theoretical hypothesis of Wallace (2014) explaining that external auditor service is crucial in serving highly credible financial statement. Since external audit adoption is still fairly new in these test samples, when corporate is willing to spend a higher budget to afford public accountant service, this decision is believed to have a positive impact on the business drive strategy. Business environment (BUSENV) describes a bad business environment and shows positive correlation with external audit adoption. This findings supports the World Bank's statement that the business environment holds high impact upon SMEs growth, this is why companies that operate in a bad business environment could leverage external auditor service adoption to ensure sustainability of its business operation (Schiffer \& Weder, 2001). Financial structure (FINSTRU) also supports the research on a company's financial structure to eventually contract external audit services. If a company's financial structure also consists of external sources, audit adoption is believed to be an essential content within the financial statement. The motion also supports the research by Palazuelos et al. (2017) that information within financial structure also has an impact on loan officers' willingness to grant them business loans.

Regression results portray sales significant position, this illustrates audit adoption has a significant impact on sales for each company. The higher sales value of the company, the more complex internal business process become. Elkhatib \& Kamel (2013) support that external audit role is pivotal for accounting policies and practices review. Thus, the research conclude the sales variable to be included in the company decision to contract an external auditor. Next, the research looks further on the country, and makes Vietnam as a benchmark. Explicitly, audit adoption is significantly higher in Malaysia and the Philippines than in Vietnam. When compared to Vietnam, however, audit adoption is significantly lower in Indonesia, both in terms of awareness and implementation. This deduction requires further study into the subject, the initial hypothesis suggests that the culture and history of a country affect companies' tendency to adopt audit within the country border.

Next, the business sector variable is analyzed with the manufacturing sector as benchmark shows no significant relationship between audit adoption in other retail or service sectors. Lastly, based on company ownership structure, the research will consider sole proprietorship as the benchmark in this dummy variable. The research combines private, public and partnership-based company ownership due to limited samples on private and public corporate in some of the observed countries. The data shows that partnership (OWNST_PS) has a significant impact on audit adoption when compared to sole proprietorship. This finding aligns with Collins (2009) who states that demand for voluntary 
audit by a small company is influenced heavily by shareholders compared to its external counterparts. In summary, when a company is co-owned by several individuals, the company will ultimately utilize external auditor service.

Table 5. Baseline Regression

\begin{tabular}{|c|c|c|c|c|}
\hline \multirow{2}{*}{ No } & \multirow{2}{*}{ Variables } & Model 1 & Model 2 & Model 3 \\
\hline & & LPM & Probit & Logit \\
\hline \multirow[t]{2}{*}{1} & SALES & $0,040 * * *$ & $0,150 * * *$ & $0,260 * * *$ \\
\hline & & $(0,009)$ & $(0,032)$ & $(0,056)$ \\
\hline \multirow[t]{2}{*}{2} & C_ID & $-0,003$ & $-0,112$ & $-0,165$ \\
\hline & & $(0,021)$ & $(0,080)$ & $(0,143)$ \\
\hline \multirow[t]{2}{*}{3} & C_MY & $0,245^{* * *}$ & $0,731 * * *$ & $1,236 * * *$ \\
\hline & & $(0,022)$ & $(0,077)$ & $(0,132)$ \\
\hline \multirow[t]{2}{*}{4} & C_PH & $0,569 * * *$ & $1,630 * * *$ & $2,712 * * *$ \\
\hline & & $(0,021)$ & $(0,076)$ & $(0,133)$ \\
\hline \multirow[t]{2}{*}{5} & C_TH & 0,034 & 0,123 & 0,185 \\
\hline & & $(0,022)$ & $(0,080)$ & $(0,141)$ \\
\hline \multirow[t]{2}{*}{6} & BSEC_OS & 0,018 & 0,071 & 0,133 \\
\hline & & $(0,017)$ & $(0,060)$ & $(0,104)$ \\
\hline \multirow[t]{2}{*}{7} & BSEC_RS & 0,010 & 0,051 & 0,106 \\
\hline & & $(0,019)$ & $(0,070)$ & $(0,122)$ \\
\hline \multirow[t]{2}{*}{8} & OWNST_PS & $-0,042 * * *$ & $-0,142 * * *$ & $-0,237 * * *$ \\
\hline & & $(0,014)$ & $(0,052)$ & $(0,090)$ \\
\hline \multirow[t]{2}{*}{9} & FINSTRU & $0,031 * * *$ & $0,092 * *$ & $0,154 * *$ \\
\hline & & $(0,011)$ & $(0,038)$ & $(0,065)$ \\
\hline \multirow[t]{2}{*}{10} & BUSDRIVE & $0,047 * * *$ & $0,166^{* * *}$ & $0,291 * * *$ \\
\hline & & $(0,008)$ & $(0,030)$ & $(0,052)$ \\
\hline \multirow[t]{4}{*}{11} & BUSENV & $0,078 * * *$ & $0,252 * * *$ & $0,429 * * *$ \\
\hline & & $(0,011)$ & $(0,041)$ & $(0,070)$ \\
\hline & Constant & $-0,162 * * *$ & $-2,147 * * *$ & $-3,675 * * *$ \\
\hline & & $(0.049)$ & $(0.178)$ & $(0.311)$ \\
\hline \multicolumn{2}{|c|}{ Observations } & 3813 & 3813 & 3813 \\
\hline \multicolumn{5}{|c|}{ Standard errors in parentheses } \\
\hline \multicolumn{5}{|c|}{$* * * p<0,01 ; * * p<0,05 ; * p<0,1$} \\
\hline \multicolumn{2}{|c|}{ Pseudo R2 } & & 0,239 & 0,239 \\
\hline \multicolumn{2}{|c|}{ LR Chi2 } & & 1183,66 & 1182,30 \\
\hline \multicolumn{2}{|l|}{$\mathrm{F}$} & 145 & & \\
\hline \multicolumn{2}{|l|}{$\mathrm{R} 2$} & 0,296 & & \\
\hline \multicolumn{2}{|c|}{$\%$ Correctly Classified } & $64,99 \%$ & $77,81 \%$ & $77,76 \%$ \\
\hline
\end{tabular}

\section{Elaborate Regression}

Furthermore, the results of additional regression is reported by performing elaborate regression between the control variable dummy and the variable of interest sequentially to see the interaction of each variable of interest with the dummy variable. As shown in Table 6, the research performs a regression to see the interaction of the dummy variable with our three variables of interest. Each model shows interaction between control variables with the 
respective variable of interest. Table 6 presents the estimated coefficients and p-values in parentheses. The results also shows promising results for Indonesian region compared to Vietnam. Indonesia shows significant hesitation towards audit adoption. As indicated by the interaction values for the relevant variables, Indonesia had values of 0,$636 ; 1,150$; and 0,802 . In contrast to Vietnam, Indonesia demonstrated consistent stand-alone results on the FINSTRU variable, which is non-audit adopting. However, when the interaction of the three variables is considered, Indonesia demonstrates a significantly higher rate of audit adoption than Vietnam. In aggregate, Indonesia, Malaysia, and the Philippines have a statistically significant level of audit adoption of 1\%, according to FINSTRU, BUSDRIVE, and BUSENV compared to the benchmark country, Vietnam. The statistical significance used is: * at the $10 \%$ level, $* *$ at the $5 \%$ level, $* * *$ at the $1 \%$ level respectively.

Table 6. Extended Model Regression Result, Country Dummies

\begin{tabular}{|c|c|c|c|c|}
\hline \multirow{2}{*}{ No } & \multirow{2}{*}{ VARIABLES } & Model 4 & Model 5 & Model 6 \\
\hline & & FINSTRU & BUSDRIVE & BUSENV \\
\hline \multirow[t]{2}{*}{1} & SALES & $0,230 * * *$ & $0,182 * * *$ & $0,200 * * *$ \\
\hline & & $(0,054)$ & $(0,055)$ & $(0,055)$ \\
\hline \multirow[t]{2}{*}{2} & FINSTRU & 0,027 & $0,150 * *$ & $0,134 * *$ \\
\hline & & $(0,163)$ & $(0,066)$ & $(0,067)$ \\
\hline \multirow[t]{2}{*}{3} & BUSDRIVE & $0,259 * * *$ & $-0,293 * *$ & $0,274 * * *$ \\
\hline & & $(0,051)$ & $(0,135)$ & $(0,051)$ \\
\hline \multirow[t]{2}{*}{4} & BUSENV & $0,424 * * *$ & $0,427 * * *$ & 0,221 \\
\hline & & $(0,070)$ & $(0,070)$ & $(0,147)$ \\
\hline \multirow[t]{2}{*}{5} & C_MY & $1,220 * * *$ & 0,085 & $0,976^{* * *}$ \\
\hline & & $(0,252)$ & $(0,308)$ & $(0,172)$ \\
\hline \multirow[t]{2}{*}{6} & C_PH & $2,333 * * *$ & $0,886^{* * *}$ & $2,539 * * *$ \\
\hline & & $(0,272)$ & $(0,334)$ & $(0,188)$ \\
\hline \multirow[t]{2}{*}{7} & C_TH & 0,046 & 0,166 & 0,106 \\
\hline & & $(0,274)$ & $(0,327)$ & $(0,176)$ \\
\hline \multirow[t]{2}{*}{8} & C_ID & $-0,847 * * *$ & $-2,187 * * *$ & $-0,644 * * *$ \\
\hline & & $(0,287)$ & $(0,333)$ & $(0,201)$ \\
\hline \multirow[t]{2}{*}{9} & 1.C_MY\#VIR & $-0,028$ & $0,559 * * *$ & 0,277 \\
\hline & & $(0,190)$ & $(0,160)$ & $(0,190)$ \\
\hline \multirow[t]{2}{*}{10} & 1.C_PH\#VIR & 0,320 & $0,980 * * *$ & 0,112 \\
\hline & & $(0,256)$ & $(0,180)$ & $(0,204)$ \\
\hline \multirow[t]{2}{*}{11} & 1.C_TH\#VIR & 0,065 & $-0,101$ & $-0,296$ \\
\hline & & $(0,216)$ & $(0,173)$ & $(0,260)$ \\
\hline \multirow[t]{4}{*}{12} & 1.C_ID\#VIR & $0,636^{* * *}$ & $1,150 * * *$ & $0,802 * * *$ \\
\hline & & $(0,234)$ & $(0,169)$ & $(0,235)$ \\
\hline & Constant & $-3,359 * * *$ & $-2,173^{* * *}$ & $-3,190 * * *$ \\
\hline & & $(0,353)$ & $(0,387)$ & $(0,324)$ \\
\hline \multicolumn{2}{|c|}{ Observations } & 3,813 & 3,813 & 3,813 \\
\hline \multicolumn{5}{|c|}{ Standard errors in parentheses } \\
\hline \multicolumn{5}{|c|}{$* * * p<0,01 ; * * p<0,05 ; * p<0,1$} \\
\hline \multicolumn{2}{|c|}{ Pseudo R2 } & 0,239 & 0,257 & 0,241 \\
\hline \multicolumn{2}{|c|}{ LR Chi2 } & 1186,10 & 1273,27 & 1191,89 \\
\hline \multicolumn{2}{|c|}{$\%$ Correctly Classified } & $77,68 \%$ & $78,18 \%$ & $77,71 \%$ \\
\hline
\end{tabular}


Table 7 reports the results of additional regressions with the business sector dummy. It is seen that the impact of business sector retail service and other service does not have significant impact on audit adoption compared to manufacturing companies. This supports the results from previous baseline regression based on complexity within the interaction presented. The table presents estimated coefficients and p-values in parentheses. The statistical significance used is: ${ }^{*}$ at the $10 \%$ level, $* *$ at the $5 \%$ level, $* * *$ at the $1 \%$ level respectively.

Table 7. Extended Model Regression Result, Business Sector Dummies

\begin{tabular}{|c|c|c|c|c|}
\hline \multirow{2}{*}{ No } & \multirow{2}{*}{ VARIABLES } & Model 7 & Model 8 & Model 9 \\
\hline & & FINSTRU & BUSDRIVE & BUSENV \\
\hline \multirow[t]{2}{*}{1} & SALES & $0,289 * * *$ & $0,286 * * *$ & $0,288 * * *$ \\
\hline & & $(0,047)$ & $(0,047)$ & $(0,047)$ \\
\hline \multirow[t]{2}{*}{2} & FINSTRU & $-0,063$ & 0,004 & 0,001 \\
\hline & & $(0,071)$ & $(0,057)$ & $(0,057)$ \\
\hline \multirow[t]{2}{*}{3} & BUSDRIVE & $0,296 * * *$ & $0,302 * * *$ & $0,290 * * *$ \\
\hline & & $(0,045)$ & $(0,051)$ & $(0,045)$ \\
\hline \multirow[t]{2}{*}{4} & BUSENV & $0,672 * * *$ & $0,670 * * *$ & $0,649 * * *$ \\
\hline & & $(0,060)$ & $(0,060)$ & $(0,074)$ \\
\hline \multirow[t]{2}{*}{5} & BSEC_OS & $-0,102$ & 0,276 & 0,015 \\
\hline & & $(0,174)$ & $(0,217)$ & $(0,122)$ \\
\hline \multirow[t]{2}{*}{6} & BSEC_RS & $-0,134$ & $-0,004$ & 0,051 \\
\hline & & $(0,201)$ & $(0,228)$ & $(0,142)$ \\
\hline \multirow[t]{2}{*}{7} & 1.BSEC_OS\#VIR & 0,065 & $-0,180$ & $-0,088$ \\
\hline & & $(0,138)$ & $(0,115)$ & $(0,145)$ \\
\hline \multirow[t]{4}{*}{8} & 1.BSEC_RS\#VIR & $0,344 * *$ & 0,149 & $0,327^{*}$ \\
\hline & & $(0,166)$ & $(0,131)$ & $(0,179)$ \\
\hline & Constant & $-2,953 * * *$ & $-3,016^{* * *}$ & $-2,994 * * *$ \\
\hline & & $(0,245)$ & $(0,246)$ & $(0,242)$ \\
\hline \multicolumn{2}{|c|}{ Observations } & 3813 & 3813 & 3813 \\
\hline \multicolumn{5}{|c|}{ Standard errors in parentheses } \\
\hline \multicolumn{5}{|c|}{$* * * p<0,01 ; * * p<0,05 ; * p<0,1$} \\
\hline \multicolumn{2}{|c|}{ Pseudo R2 } & 0,074 & 0,074 & 0,074 \\
\hline \multicolumn{2}{|c|}{ LR Chi2 } & 368,72 & 368,76 & 368,75 \\
\hline \multicolumn{2}{|c|}{$\%$ Correctly Classified } & $68,37 \%$ & $68,19 \%$ & $68,27 \%$ \\
\hline
\end{tabular}

Finally, Table 8 summarizes additional regression results that contribute to the creation of the dummy ownership structure. When we consider the business sector as a whole, there is no discernible difference between baseline and elaborated regression. The estimated coefficients and $\mathrm{p}$-values are presented in parentheses. The statistical significance are: ${ }^{*}$ at the $10 \%$ level, $* *$ at the $5 \%$ level, *** at the $1 \%$ level respectively. 
Table 8. Extended Model Regression Result, Ownership Structure Dummies

\begin{tabular}{|c|c|c|c|c|}
\hline \multirow{2}{*}{ NO } & \multirow{2}{*}{ VARIABLES } & \multirow{2}{*}{$\begin{array}{l}\text { Model } 10 \\
\text { FINSTRU } \\
\end{array}$} & \multirow{2}{*}{$\begin{array}{c}\text { Model } 11 \\
\text { BUSDRIVE }\end{array}$} & \multirow{2}{*}{$\begin{array}{l}\text { Model } 12 \\
\text { BUSENV }\end{array}$} \\
\hline & & & & \\
\hline \multirow[t]{2}{*}{1} & SALES & $0,275 * * *$ & $0,272 * * *$ & $0,273 * * *$ \\
\hline & & $(0,048)$ & $(0,048)$ & $(0,048)$ \\
\hline \multirow[t]{2}{*}{2} & FINSTRU & 0,080 & $-0,002$ & $-0,001$ \\
\hline & & $(0,091)$ & $(0,057)$ & $(0,057)$ \\
\hline \multirow[t]{2}{*}{3} & BUSDRIVE & $0,277 * * *$ & $0,285 * * *$ & $0,279 * * *$ \\
\hline & & $(0,045)$ & $(0,064)$ & $(0,045)$ \\
\hline \multirow[t]{2}{*}{4} & BUSENV & $0,662 * * *$ & $0,665^{* * *}$ & $0,630 * * *$ \\
\hline & & $(0,060)$ & $(0,060)$ & $(0,093)$ \\
\hline \multirow[t]{3}{*}{5} & OWNST_PS & $0,233^{*}$ & 0,121 & 0,063 \\
\hline & & $(0,141)$ & $(0,161)$ & $(0,099)$ \\
\hline & 1.OWNST_PS\#VI & & & \\
\hline \multirow[t]{3}{*}{6} & $\mathrm{R}$ & $\begin{array}{l}-0,134 \\
(0,116)\end{array}$ & $\begin{array}{l}-0,015 \\
(0,085)\end{array}$ & $\begin{array}{c}0,060 \\
(0,120)\end{array}$ \\
\hline & Constant & $-3,014 * * *$ & $-2,933 * * *$ & $-2,914 * * *$ \\
\hline & & $(0,254)$ & $(0,247)$ & $(0,242)$ \\
\hline \multicolumn{2}{|l|}{ Observations } & 3813 & 3813 & 3813 \\
\hline \multicolumn{5}{|c|}{ Standard errors in parentheses } \\
\hline \multicolumn{5}{|c|}{$* * * p<0,01, * * p<0,05, * p<0,1$} \\
\hline \multicolumn{2}{|c|}{ Pseudo R2 } & 0,073 & 0,073 & 0,073 \\
\hline \multicolumn{2}{|c|}{ LR Chi2 } & 362,67 & 361,36 & 361,56 \\
\hline \multicolumn{2}{|c|}{$\%$ Correctly Classified } & $68.06 \%$ & $68.37 \%$ & $68.53 \%$ \\
\hline
\end{tabular}

\section{Robustness Check}

Table 9 reports regression robustness check for proxy: FINSTRU, BUSDRIVE dan BUSENV. Robustness check is conducted by inserting variables of interest in sequential manner. Each regression (shown on the first row of each table) is processed by using the LOGIT regression model. This report serves an estimated coefficient with enclosed p-value. In practice, level of significance statistic used are: * on $10 \%$ error level, $* *$ on $5 \%$ error level, *** on $1 \%$ error level consecutively. Through sequential regression upon variable of interest, the regression model could be deemed as robust. This claim is based on the relative magnitude and level of significance for each variable shown consistent results even when the variable of interest is being input in sequential manners. Even though each variable of interest is submitted in a sequential manner, Pseudo R2, LR Chi or correctly classified percentage does not show significant results, so it is concluded that each variable of interest is independent of each other. 
Table 9. Robustness Check - Sequential

\begin{tabular}{|c|c|c|c|c|c|}
\hline \multirow{2}{*}{ No } & \multirow{2}{*}{ Variables } & Model 3 & Model 14 & Model 15 & Model 16 \\
\hline & & Logit & Logit & Logit & Logit \\
\hline \multirow[t]{2}{*}{1} & SALES & $0,260 * * *$ & $0,285 * * *$ & $0,332 * * *$ & $0,277 * * *$ \\
\hline & & $(0,056)$ & $(0,055)$ & $(0,054)$ & $(0,055)$ \\
\hline \multirow[t]{2}{*}{2} & C_ID & $-0,165$ & $-0,167$ & $-0,284 * *$ & $-0,238^{*}$ \\
\hline & & $(0,143)$ & $(0,143)$ & $(0,142)$ & $(0,142)$ \\
\hline \multirow[t]{2}{*}{3} & C_MY & $1,236 * * *$ & $1,281 * * *$ & $1,173 * * *$ & $1,171 * * *$ \\
\hline & & $(0,132)$ & $(0,131)$ & $(0,131)$ & $(0,130)$ \\
\hline \multirow[t]{2}{*}{4} & C_PH & $2,712 * * *$ & $2,687 * * *$ & $2,668 * * *$ & $2,725 * * *$ \\
\hline & & $(0,133)$ & $(0,133)$ & $(0,133)$ & $(0,132)$ \\
\hline \multirow[t]{2}{*}{5} & C_TH & 0,185 & 0,204 & 0,186 & 0,010 \\
\hline & & $(0,141)$ & $(0,141)$ & $(0,141)$ & $(0,137)$ \\
\hline \multirow[t]{2}{*}{6} & BSEC_OS & 0,133 & 0,127 & 0,114 & 0,128 \\
\hline & & $(0,104)$ & $(0,104)$ & $(0,104)$ & $(0,104)$ \\
\hline \multirow[t]{2}{*}{7} & BSEC_RS & 0,106 & 0,101 & 0,046 & 0,109 \\
\hline & & $(0,122)$ & $(0,122)$ & $(0,121)$ & $(0,121)$ \\
\hline \multirow[t]{2}{*}{8} & OWNST_PS & $-0,237 * * *$ & $-0,235 * * *$ & $-0,184^{* *}$ & $-0,175^{* *}$ \\
\hline & & $(0,090)$ & $(0,089)$ & $(0,089)$ & $(0,089)$ \\
\hline \multirow[t]{2}{*}{9} & FINSTRU & $0,154 * *$ & & $0,184 * * *$ & $0,183 * * *$ \\
\hline & & $(0,065)$ & & $(0,065)$ & $(0,065)$ \\
\hline \multirow[t]{2}{*}{10} & BUSDRIVE & $0,291 * * *$ & $0,301 * * *$ & & $0,352 * * *$ \\
\hline & & $(0,052)$ & $(0,052)$ & & $(0,051)$ \\
\hline \multirow[t]{4}{*}{11} & BUSENV & $0,429 * * *$ & $0,441 * * *$ & $0,506 * * *$ & \\
\hline & & $(0,070)$ & $(0,070)$ & $(0,069)$ & \\
\hline & Constant & $-3,675 * * *$ & $-3,681 * * *$ & $-3,627 * * *$ & $-3,656 * * *$ \\
\hline & & $(0,311)$ & $(0,312)$ & $(0,311)$ & $(0,309)$ \\
\hline \multicolumn{2}{|l|}{ Observations } & 3813 & 3813 & 3813 & 3813 \\
\hline \multicolumn{6}{|c|}{ Standard errors in parentheses } \\
\hline \multicolumn{6}{|c|}{$* * * p<0,01 ; * * p<0,05 ; * p<0,1$} \\
\hline \multicolumn{2}{|l|}{ Pseudo R2 } & 0,239 & 0,238 & 0,232 & 0,231 \\
\hline \multicolumn{2}{|c|}{ LR Chi2 } & 1182,30 & 1176,81 & 1151,26 & 1144,95 \\
\hline \multicolumn{2}{|c|}{$\%$ Correctly Classified } & $77,76 \%$ & $78,05 \%$ & $78,15 \%$ & $77,00 \%$ \\
\hline
\end{tabular}

\section{CONCLUSIONS}

The purpose of this research is to ascertain the factors that influence SMEs' decision to adopt audit. Specifically, the research aims to examine how the identified variables of interest (financial structure, business motivation, and business environment) influence the decision to adopt external auditing by ASEAN SMEs, Additional research is conducted to incorporate several control variables into the analysis, including sales, country, business sector, and ownership structure. The initial model is largely supported by adequate specification and bolstered by robustness tests.

As a straightforward application on audit adoption, the research uses the ordinal logistic regression. Upon testing and reviewing variables and data, it is found that audit have positive correlation with financial structure, business drive, and business environment. This 
indicates three of our predetermined variables have contribution on audit adoption decision, especially for SMES. As for the control variables, there seems to be no significant correlation between the business sector of a company with the tendency to adopt audit as part of SMEs business processes. For the ownership structure, there is a significant negative correlation between this variable with external audit decisions for SMEs companies. However, the research discovers a significant positive correlation between audit adoption and sales in the case of audits. This implies that a higher sales value may influence an SME's decision to adopt audit. This could happen since businesses with a higher sales value also have a higher earnings value, implying that their business processes are more complex. This results in a significant amount of audit adoption within the observation scope. In addition, according to country of origin research, there is a significant positive correlation to adopt audit in the country of Malaysia, Philippines as opposed to Thailand and Vietnam. In Indonesia, awareness of audit adoption is relatively insignificant compared to the other variables examined in the research.

Additionally, the research discovers that there is no significant differences between baseline regressions of each control variable and the respective variable of interest; BSECS and OWNSTRUC. Distinction is found through a complex regression analysis based on country of origin. For example, previously on baseline regression, Indonesia showed low adoption rate when observed with variable of interest. Now, it comes up with showing different results. The result indicates a significant positive relationship between external audit adoption in Indonesia with three of our predetermined variables of interest. This could indicate that, when viewed through the lens of the country of origin, external audit adoption is a complicated process.

As a matter of fact, additional research is required to examine the business motivations and business environment factors that influence a business entity's decision to adopt audit. Additionally, it would increase SMEs' awareness of the business benefits of audit adoption. This variable may also provide a different angle for a business considering external auditor services, apart from the cost and potential profit associated with that decision. Correspondingly, there is room for additional research on ownership structure and sales variables as this research does not examine those variables due to resource constraints.

It is hoped that by the end of this research, the variable of interest will be a factor in business owners' decision to hire external auditors. Particularly in Indonesia, these findings may encourage businesses to consider cost-benefit analysis, as business drive has had a significant impact on the adoption of external auditing. As for business environment, it is expected that businesses operating in unfavorable business environments will consider utilizing external audit to help them improve their business processes. The research serves as a literature review on auditing for scientific purposes and lays the groundwork for future research.

In terms of the regulatory body, this research, particularly the financial structure proxy, can be used as supporting literature for any auditor-related regulator who has an impact on SMES, particularly those who will use SMEs ownership structure as a criterion for 
regulation. As a proxy for business drive, it is expected that the research provides a new perspective on the use of external auditors and contributes to the growth of small and medium-sized businesses by advocating for a more transparent application of audit fees. This would educate businesses about the detailed impact of service costs on each business line. Lastly, regulatory bodies could make use of the business environment proxy to enrich the auditing process for SMEs in unfavorable business environments. In the long run, regulators could also offer incentive and support toward SMEs to adopt external auditor service adoption. With numerous accomplishments, it is hoped that external auditor services will be widely adopted to boost growth and ultimately benefit the economies of developing countries. Furthermore, regulators could also offer incentive and support toward SMEs to adopt external auditor service adoption. With many success test cases, external auditor services is expected to be widely adopted to boost growth and ultimately benefit the economies of developing countries. Due to resource limitation, further research is required upon multidimensional components and variables for better clarity on key factors that result in SMEs adoption of audit in a more specific manner.

\section{ABOUT THE AUTHORS}

Jonathan is a master of accounting student at Bina Nusantara University majoring in accounting. Currently he is building a career in an internet service providers business in Indonesia as a general ledger analyst. His passion for audit science made him interested in doing research on audit science.

Moch. Doddy Ariefianto (Doddy) has been a permanent Lecturer at the Master of Accounting Study Program, Bina Nusantara University since August 2019. He graduated for Masters and Doctoral degrees in Economics in 2005 and 2010 from the University of Indonesia. Doddy's research interests are Banking, Financial Markets, Corporate Finance, International Finance and Financial Regulation. His scientific articles have been published in reputable international and national publications such as Economic Systems, Research in Business and Finance, Borsa Istanbul Review, Economic Bulletin, International Journal of Economic and Management, Bulletin of Monetary Economics and Banking, Indonesian Capital Market Review, Ventura and Journal of Finance Banking. The book that has been published is Econometrics: The Essence and Application using Eviews (Erlangga, 2012).

Rindang Widuri, is an Assistant Professor, and Head of Master of Accounting Program at Bina Nusantara University, Jakarta, Indonesia. She earned B.Sc and Master degrees in Accounting Information Systems from Bina Nusantara University, and Ph.D in Accounting from RMIT University, Australia. Her primary area of expertise is the adoption of technology in financial reporting and accounting education. She has awarded several research grants from international (Australia Awards) and national institutions (Directorate of Higher Education, Ministry of National Education, Indonesia). 


\section{REFERENCES}

Anuar, E, Devi, S, \& Meng, C. (2012). Audit exemption for Malaysian SMEs: Does ownership matter? Asian Journal of Accounting Perspectives, 5(1), 1-22. https://doi.org/10.22452/AJAP.vol5no1.1

Carey, P., Simnett, R., \& Tanewski, G. (2000). Voluntary demand for internal and external auditing by family businesses. A Journal of Practice \& Theory, 19(1), 37-51. https://doi.org/10.2308/aud.2000.19.s-1.37

Cleff, T. (2019). Applied Statistics and Multivariate Data Analysis for Business and Economics; A Modern Apporach using SPSS, Stata and Excel (1 ${ }^{\text {st }}$ Ed.). (2019). Switzerland: Springer.

Collis, J. (2009). Auditing and accounting requirements for SMEs in the UK: A benefit or a burden? $5^{\text {th }}$ Annual Workshop on Accounting in Europe.

Coetzee, F. \& Buys, P. (2017). The impact of the independent review on SME access to bank finance: The case of South Africa. Banks and Bank Systems, 12(1), 135-142. http://dx.doi.org/10.21511/bbs.12(1-1).2017.06

Desender, K., Cestona, A., Crespi, R., \& Aguilera, R. (2009). Board Characteristic and Audit Fees: Why Ownership Structure Matters? Working Papers 09-0107. University of Illinois at Urbana Campaign, College of Business.

Elkhatib, S. \& Kamel, H. (2013). The perceptions of audit comittees' role in an emerging market: the case of Egypt. Journal of Economic and Administrative Sciences, 29(2), 85-98. http://dx.doi.org/10.1108/JEAS-09-2013-0028

Hay, D. (2020). The Future of Auditing ( $1^{\text {st }}$ Ed.). Routledge.

Hien, T., Abbott, M., \& Huyen, V. (2016). The impact of the use of independent auditing on credit accessibility: The case of Vietnamese SMEs. VNU Journal of Science: Education Research, 32(5E), 44-54.

Hermas, R. \& Tahavainen, A-J. (2002). Ownership and Financial Structure of Biotechnology SMEs: Evidence from Finland. Discussion Paper No. 835. The Research Institute of the Finnish Economy (ETLA), Helsinki.

Irmawan, Y., Hudaib, M., \& Hannifa, R. (2013). Exploring the perceptions of auditor independence in Indonesia. Journal of Islamic Accounting and Business Research, 4(2), 173-202. https://doi.org/10.1108/JIABR-09-2012-0061

Kamarudin, N. \& Abidin, Z. Z. (2012). Audit exemption among SMEs in Malaysia. Asian Review of Accounting, 20(2), 152-162. https://doi.org/10.1108/13217341211242196 
Kesting, P. \& Günzel-Jensen, F. (2015). SMEs and new ventures need business model $\begin{array}{llll}\text { sophistication. } & \text { Business } & \text { 285-293. }\end{array}$ https://doi.org/10.1016/j.bushor.2015.01.002

Louis, H. (2005). Acquirers' abnormal returns and the non-Big 4 auditor clientele effect. Journal of Accounting \& Economics, 40(1), 75-99. http://dx.doi.org/10.1016/j.jacceco.2005.03.001

Marolt, M., Lenart, G., Maletic, D., Brostnar, M., \& Pucihar, A. (2016). Business model innovation: Insights from a multiple case study of Slovenian SMEs. Organizacija, 49(3), 161-171. https://doi.org/10.1515/orga-2016-0015

Olawale, F. \& Smit, V. (2010). Business environmental influences on the availability of debt to new SMEs in South Africa. African Journal of Business Management, 4(9), 17901799. https://doi.org/10.5897/AJBM.9000122

Palazuelos, E. Crespo, A., \& Corte J. (2017). Accounting information quality and trust as determinants of credit granting to SMEs: The role of external audit. Small Business Economics, 51(4), 861-877. https://doi.org/10.1007/s11187-017-9966-3

Peel, M \& Bridge, J. (1999). Planning, business objectives and capital budgeting in Japanese, German and domestic SMEs: Some evidence from the UK manufacturing sector. Journal of Small Business and Enterprise Development, 6(4), 350-365. https://doi.org/10.1108/eum0000000006690

Schiffer, M \& Weder, B. (2001). Firm Size and the Business Environment: Worldwide Survey Results. IFC Discussion Paper No. 43. Washington, DC: World Bank and the International Finance Corporation.

Senkow, D. W., Rennie, M. D., Rennie, R. D., \& Wong, J. W. (2001). The audit retention decision in the face of deregulation: Evidence from large private Canadian corporations. Auditing A Journal of Practice \& Theory, 20(2), 101-113. https://doi.org/10.2308/aud.2001.20.2.101

Wallace, W. (2004). The economic role of the audit in free and regulated markets: A look back and a look forward. Research in Accounting Regulation, 17(1), 267-298. http://dx.doi.org/10.1016/S1052-0457(04)17012-4

Van Caneghem, T. \& Campenhout, G. (2010). Quantity and quality of information and SME financial structure. Small Business Economics, 39(2), 341-358. https://doi.org/10.1007/s11187-010-9306-3

Vanstraelen, A. \& Schelleman, C. (2017). Auditing private companies: What do we know? Accounting and Business Research, 565-584. https://doi.org/10.1080/00014788.2017.1314104 
Voulgaris, F., Asteriou, D., \& Agiomigianakis, G. (2000). Financial development and financial structures of industrial SMEs: The case Of Greece. European Research Studies, 3(3-4), 95-110. 